\title{
Controlled trial of speech therapy versus oxprenolol for stammering
}

\author{
LENA RUSTIN, A KUHR, P J COOK, I M JAMES
}

\begin{abstract}
In a controlled trial of treatment for stammering under stress oxprenolol (40 mg) compared with placebo was assessed in a double-blind manner over two days, six weeks apart, in 31 stammerers before and after speech therapy. The trial design also allowed six weeks of intensive speech therapy, using a slowed-speech and relaxation technique, to be compared with no treatment and assessed single-blind. Oxprenolol produced a significant fall in pulse rate and systolic blood pressure but no overall change in performance either before or after speech therapy. Intensive speech therapy produced a highly significant improvement in the global performance of untrained subjects $(p<0.001)$ and a significant reduction in the number $(p<0.001)$ and duration $(p<0.001)$ of blocks. Maintenance speech therapy tended to produce further improvement in trained subjects.

Speech therapy is apparently an effective treatment for stammering, whereas oxprenolol appears to be of no value when given routinely; oxprenolol may be of value, however, in very stressful conditions.
\end{abstract}

\section{Introduction}

Various treatments have been used to control stammering but the most common now employed include specific speech-

Camden and Islington Area Health Authority (Teaching), London WC1

LENA RUSTIN, LCST, area speech therapist

Department of Psychology, Hanover Medical School, Hanover, W Germany

A KUHR, DIP PSYCH, DR RER NAT, senior lecturer

Section of Clinical Pharmacology, Medical Unit, Royal Free Hospital, London NW3 2QG

$P$ J COOK, BSC, MRCP, lecturer

I M JAMES, PHD, FRCP, senior lecturer in medicine and honorary consultant physician control techniques, such as delayed auditory feedback, masking, and syllable-timed, prolonged, or slowed speech. ${ }^{1-3}$ Psychotherapy, ${ }^{4}$ hypnotherapy, ${ }^{5}$ and behaviour therapy ${ }^{6}{ }^{7}$ are sometimes used as additional measures. Stammering tends to be worse when the subject is anxious, and many speech therapists use a combination of speech control and relaxation techniques. ${ }^{13}$ 8 None of these treatments is firmly established, however, since all of the favourable studies reported ${ }^{1-8}$ were either uncontrolled or subject to bias owing to open methods of assessment.

Tranquillising drugs used to reduce speech anxiety have been unsatisfactory. In one open study reserpine, meprobamate, and chlorpromazine all failed to improve performance. ${ }^{9}$ Haloperidol was partially effective in two other randomised controlled trials. ${ }^{1011}$ This agent apparently reduced the duration but not the number of disfluencies, and it has several potentially serious side effects. Since the beta-adrenergic-blocking agent oxprenolol reportedly improves performance of skilled tests carried out under stressful conditions, ${ }^{12}{ }^{13}$ we thought that the drug might have a beneficial effect on stammering as well. This study was therefore designed as a randomised double-blind cross-over trial to compare oxprenolol $(40 \mathrm{mg}$ ) with placebo for improving stammering associated with stress. The drug was assessed in both trained and untrained subjects, since untrained subjects were more likely to be anxious. The design also allowed a controlled single-blind assessment to be made of the effect of speech therapy in untrained subjects.

\section{Subjects and methods}

An unselected group of 31 stammerers (26 men, five women) aged 18-55 (mean 29) years who had been referred for speech therapy gave informed consent to the trial. All were physically healthy, and none had a history of asthma or mental illness.

Speech therapy-The first 14 referrals (group A; table I) began a six-week speech therapy course consisting of 20 individual and intensive one-hour sessions given daily for two weeks, thrice weekly for two weeks, and twice weekly for two weeks. The stammerers were trained using the same progressive relaxation and slowed-speech technique. ${ }^{8}$ All subsequent referrals were placed in group B and had no treatment before the first speech test. At the end of the first six weeks both groups were assessed by two speech tests given on consecutive days (assessment 1). One test was given after the subject received oxprenolol and the other after matching placebo in randomised 
order. Group B were then given intensive speech therapy for the first time, while group A received maintenance speech therapy for one hour a week. A second assessment, consisting of two further speech tests given after oxprenolol and placebo, was made at the end of the second six-week period.

TABLE I-Design of trial

\begin{tabular}{|c|c|c|}
\hline & $\begin{array}{c}\text { Group A } \\
(\mathrm{n}=14)\end{array}$ & $\begin{array}{c}\text { Group B } \\
(\mathrm{n}=17)\end{array}$ \\
\hline Speech therapy (six weeks) & Intensive treatment & No treatment \\
\hline Assessment $1\left\{\begin{array}{l}\text { Test day } 1 \\
\text { Test day } 2\end{array}\right.$ & $\begin{array}{l}\text { Drug or placebo } \\
\text { Placebo or drug }\end{array}$ & $\begin{array}{l}\text { Drug or placebo } \\
\text { Placebo or drug }\end{array}$ \\
\hline Speech therapy (six weeks) & $\begin{array}{l}\text { Maintenance treatment } \\
(n=10)\end{array}$ & $\begin{array}{l}\text { Intensive treatment } \\
(n=13)\end{array}$ \\
\hline Assessment $2\left\{\begin{array}{l}\text { Test day } 1 \\
\text { Test day } 2\end{array}\right.$ & $\begin{array}{l}\text { Placebo or drug } \\
\text { Drug or placebo }\end{array}$ & $\begin{array}{l}\text { Placebo or drug } \\
\text { Drug or placebo }\end{array}$ \\
\hline
\end{tabular}

Drug treatment-All drugs, coffee, and alcohol were forbidden on test days. The stammerers were given either oxprenolol $40 \mathrm{mg}$ or an identical matching placebo 90 minutes before the start of the test. Each subject was instructed to read from prepared material for two minutes, then to talk on a topic of their choice for two minutes, and, finally, to engage in four minutes' conversation with a mildly aggressive interviewer. The test was designed to provoke anxiety. The subject sat on a raised, brightly lit platform in front of an interviewer with an audience and two assessors looking on. The performance was videorecorded, and subjects had agreed that the recordings could be used for a radio programme.

Assessment-Pulse and blood pressure were measured after standing for three minutes immediately before the speech test. The presence and degree of nervousness were also assessed using a visual analogue scale ranging from $0 \mathrm{~mm}$ ("I feel relaxed") to $10 \mathrm{~mm}$ ("I feel terrified"). Performance was assessed by an independent psychologist and an experienced speech therapist, who did not know which drug or speech therapy regimen the subject had received. The degree of body movement, eye contact, and overall performance were assessed at the time of the trial using the visual analogue scale. The number and duration of blocks in speech and the rate of speech were analysed from the videotape recording.

Data analysis-Analysis of variance was used to assess the variations of the effects of the drugs within the groups and with the timing of administration and the unpaired $t$ test to assess differences between groups.

\section{Results}

Four subjects in each group withdrew after the first speech tests, mainly because of nervousness. These withdrawals included some of the worst stammerers; however, they were divided equally between the two groups, so that the relative scores were almost unchanged (table II).
OXPRENOLOL

The subjects in group B tended to be more nervous at the first assessment and less nervous at the second compared with the trainees, but this difference was not quite significant. No significant changes occurred in the speech test scores or in the degree of nervousness in either trained or untrained subjects after taking oxprenolol. Analysis of the timing of administration of the drugs showed that subjects taking placebo on the first day tended to do badly while those given oxprenolol were less anxious and had fewer and shorter blocks. On the second day, however, the result was reversed.

The mean erect blood pressures and pulse rates after placebo and oxprenolol were similar for the two assessments. Each pair of readings was therefore averaged to give a single value for each subject after placebo and oxprenolol. The mean values for both groups were blood pressure $125 / 76 \mathrm{~mm} \mathrm{Hg}$ and pulse $87 / \mathrm{min}$ after placebo, and blood pressure $115 / 81 \mathrm{~mm} \mathrm{Hg}$ and pulse $70 / \mathrm{min}$ after oxprenolol (systolic blood pressure, $\mathrm{p}<0.005$; diastolic blood pressure, NS; pulse, $\mathrm{p}<0.002$ ). Hence $40 \mathrm{mg}$ oxprenolol produced a significant beta-adrenergic-blocking effect when the speech tests were being carried out.

\section{SPEECH THERAPY}

The effect of speech therapy was assessed by averaging the speech test scores recorded after oxprenolol and placebo and comparing the mean scores for the two groups. At the first assessment the subjects who had received intensive speech therapy (group A) scored better than the untrained subjects in all of the speech subtests. Nevertheless, only the difference for the number of blocks per minute was significant $(p<0.05)$. Subjects in group B who completed both assessments showed a highly significant improvement after intensive speech therapy in all of the subtests except the rate of speech. The group A speech test scores tended to continue to improve with maintenance therapy apart from the rate of speech, which increased.

\section{Discussion}

The trial design required that subjects from both groups should be tested on the same days in order to ensure reproducibility of the test conditions. Unfortunately, subjects could not be randomised into the test groups before the trial began without producing an unacceptable delay in treatment during the recruitment period, particularly for subjects in group B. The sequential method of allocation that was used had the disadvantage that a time-dependent bias in allocation of subjects may have occurred. If, however, the results of the first assessment were explained by more severe stammerers having entered group B by chance then the subsequent improvement after speech therapy would be more clinically significant. Thus these results confirm that intensive speech therapy can produce a significant improvement in the performance of stammerers and that this improvement may be maintained by once-weekly maintenance therapy.

TABLE II-Combined placebo and oxprenolol speech test scores (mean $+S E M$ ) for group $A$ (speech therapy before assessment) and group B (speech therapy after assessment). Group A received maintenance speech therapy between speech tests

\begin{tabular}{|c|c|c|c|c|c|c|c|c|c|c|c|}
\hline \multicolumn{7}{|c|}{ Test variable } & \multicolumn{2}{|r|}{ Assessment $1^{*}$} & \multirow{2}{*}{ 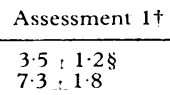 } & \multirow{2}{*}{ 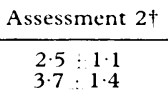 } & \multirow{2}{*}{$\begin{array}{l}\mathrm{p}_{+}^{++} \\
0.092 \\
0.001\end{array}$} \\
\hline No of blocks $/ \mathrm{min} \quad \ldots$ & . & . & .. & . & .. & $\cdots$ & $\underset{\mathrm{B}}{\mathrm{A}}$ & $\begin{array}{l}4 \cdot 4 \pm 1 \cdot 1 \S \\
8 \cdot 0: 1.5\end{array}$ & & & \\
\hline Duration of blocks $(\mathrm{s} / \mathrm{min})$. & $\cdots$ & . & $\cdots$ & . & $\cdots$ & $\cdots$ & $\begin{array}{l}\text { A } \\
\text { B }\end{array}$ & $\begin{array}{l}10 \cdot 0 \div 3 \cdot 8 \\
13 \cdot 5+3 \cdot 2\end{array}$ & $\begin{array}{r}7 \cdot 0 \div 3 \cdot 6 \\
10 \cdot 7 \div 3 \cdot 2\end{array}$ & $\begin{array}{l:l}4 \cdot 0 & 2 \cdot 5 \\
4 \cdot 0 & 1 \cdot 6\end{array}$ & $\begin{array}{l}0 \cdot 078 \\
0.001\end{array}$ \\
\hline Rate of speech (syllables/min) & $\cdots$ & . & . & $\cdots$ & $\cdots$ & $\cdots$ & $\begin{array}{l}\mathrm{A} \\
\mathrm{B}\end{array}$ & $\begin{array}{l}133=15 \cdot 2 \\
150 \div 12 \cdot 6\end{array}$ & $\begin{array}{l}142=18.0 \\
156=15.8\end{array}$ & $\begin{array}{l}152: 17 \cdot 4 \\
156: 14.7\end{array}$ & $\begin{array}{c}0.082 \\
\text { NS }\end{array}$ \\
\hline Body movement $(0=\mathrm{a}$ lot $; 100$ & $=$ none $)$ & . & $\cdots$ & $\cdots$ & $\cdots$ & $\cdots$ & $\begin{array}{l}\mathrm{A} \\
\mathrm{B}\end{array}$ & $\begin{array}{l}51 \cdot 3+3 \cdot 1 \\
51 \cdot 9+5 \cdot 5\end{array}$ & $\begin{array}{l}55 \cdot 3-4 \cdot 0 \\
49 \cdot 7: 3.5\end{array}$ & $\begin{array}{l:l}67 \cdot 0 & 6 \cdot 7 \\
67 \cdot 7 & 7 \cdot 1\end{array}$ & $\begin{array}{l}0.031 \\
0.012\end{array}$ \\
\hline Eye contact $(0=$ none $; 100=e x$ & ellent） & . & $\cdots$ & $\cdots$ & $\cdots$ & $\cdots$ & $\begin{array}{l}\mathrm{A} \\
\mathrm{B}\end{array}$ & $\begin{array}{l}64 \cdot 3: 5 \cdot 2 \\
56 \cdot 1: 3 \cdot 7\end{array}$ & $\begin{array}{l}67 \cdot 1: 5 \cdot 2 \\
57 \cdot 9: 4 \cdot 4\end{array}$ & $\begin{array}{l}67 \cdot 5: 7 \cdot 6 \\
67 \cdot 8: 6 \cdot 7\end{array}$ & $\begin{array}{c}\text { NS } \\
0.001\end{array}$ \\
\hline \multicolumn{7}{|c|}{ Global performance (visual analogue scale: $0=$ terrible $; 100=$ excellent) } & $\stackrel{\mathrm{A}}{\mathrm{B}}$ & $\begin{array}{l}56 \cdot 8 \div 6 \cdot 3 \\
50 \cdot 5: 5 \cdot 7\end{array}$ & $\begin{array}{r:r}63 & 7 \cdot 3 \\
54 \cdot 7 & 6 \cdot 7\end{array}$ & $\begin{array}{l}68: 7 \cdot 7 \\
72: 7 \cdot 7\end{array}$ & $\begin{array}{c}\text { NS } \\
0.001\end{array}$ \\
\hline
\end{tabular}


A standard dose of the beta-adrenoceptor-blocking drug oxprenolol which was sufficient to produce a significant fall in pulse rate and systolic blood pressure had no obvious effect on either overall speech performance or anxiety scores. Analysis of the results was complicated by the effect of timing of the administration of the drugs. Those subjects who took oxprenolol on the first day of each assessment tended to do better than those given placebo, while the reverse occurred on the second day. There was a tendency for performance on the second day to be similar to the first. This tendency has been reported, ${ }^{13}$ and possibly these behavioural effects were greater than the drug effects being investigated. We recommend that in future studies one group should be given placebo on both days in addition to the standard cross-over groups.

Beta-blockade is likely to be most effective in very anxious subjects, but despite efforts to make the test stressful the level of anxiety achieved was not very great. The pretest anxiety scores were much lower than those obtained in a similar study, ${ }^{13}$ in which oxprenolol had a significant effect on performance and the placebo pulse rate was lower-88 compared with 99 . We have seen several trained subjects who seemed to benefit from the drug when they were under stress, such as when being interviewed for an important post, and who requested the drug for subsequent occasions. We therefore conclude that the drug may still be of value in very anxious subjects or on stressful occasions, though there is no evidence that additional fluency can be expected when the drug is given routinely.

\section{References}

${ }^{1}$ Martin R, Haroldson S. Effects of five experimental treatments on stuttering. 7 Speech Hear Res 1979 ;22:132-46.

${ }^{2}$ Azrin NH, Nunn RG, Frantz SE. Comparison of regulated breathing versus abbreviated desensitisation on reported stuttering episodes. F Speech Hear Disord 1979;44:331-9.

${ }^{3}$ Azrin NH, Nunn RG. A rapid method of eliminating stuttering by a regulated breathing approach. Behav Res Ther 1974;12:279-86

${ }^{4}$ Moleski R, Tesi DJ. Comparative psychotherapy: rational-emotive therapy versus systematic desensitization in the treatment of stuttering. f Consult Clin Psychol 1976;44:309-11.

${ }^{5}$ Lockhart MS, Robertson AW. Hypnosis and speech therapy as a combined therapeutic approach to the problem of stammering. A study of thirty patients. British Fournal of Disorders of Communication 1977;12:97-108.

${ }^{6}$ Ingham RJ, Andrews G. Behaviour therapy and stuttering: a review. f Speech Hear Disord 1973;38:405-41.

7 Wolpe J, Lazarus AA. Behaviour therapy techniques. Oxford: Pergamon Press, 1966.

${ }^{8}$ Rustin L. An intensive group programme for adolescent stammerers British Fournal of Disorders of Communication 1978;13:85-92.

${ }^{9}$ Kent LR. The use of tranquilisers in the treatment of stuttering. 7 Speech Hear Disord $1963 ; 28: 288-94$.

10 Wells PG, Malcolm MT. Controlled trial of the treatment of 36 stutterers. Br F Psychiatry 1971;119:603-4.

11 Rosenberger PB, Wheelden JA, Kalotkin M. The effect of haloperidol on stuttering. Am f Psychiatry 1976;133:331-4.

12 James IM, Pearson RM, Griffith DNW, Newbury P. Effect of oxprenolol on stage-fright in musicians. Lancet 1977; ii:952-4

13 Siitonen L, Sonck T, Janne J. Effect of beta-blockade on performance: use of beta-blockade in bowling and shooting competitions. F Int Med Res $1977 ; \mathbf{5}: 359-66$.

(Accepted 18 fune 1981)
Department of Medicine, University of the Witwatersrand, and Johannesburg Hospital, Johannesburg, South Africa

M ZALTZMAN, FCP(SA), physician

J M KALLENBACH, MB, MRCP, senior physician

$\mathrm{G} D \mathrm{GOSS}, \mathrm{MB}, \mathrm{BCH}$, registrar

$M$ LEWIS, FCP(SA), physician

$S$ ZWI, BSC, FRCP, professor of respiratory medicine

Department of Tropical Medicine, South African Institute for Medical Research, Johannesburg

J H S GEAR, MD(HON), FRCP, honorary professor of tropical medicine

\section{Introduction}

The adult respiratory distress syndrome (non-cardiogenic pulmonary oedema ${ }^{1}$ ) may complicate infection caused by a wide variety of micro-organisms. ${ }^{2}$ Its occurrence in leptospirosis has not been proved. We report a case of Leptospira canicola infection in which the pulmonary findings and haemodynamic measurements were consistent with the syndrome.

\section{Case history}

A 28-year-old white man was admitted to the Johannesburg Hospital after a camping trip during which he had come into contact with dogs and goats. Headache, fever, diarrhoea, and a non-productive cough had been present for four days. He was tachypnoeic and cyanosed with a temperature of $39 \cdot 2^{\circ} \mathrm{C}$ and had noticeable conjunctival suffusion. Diffuse pulmonary crepitations were heard but there was no evidence of cardiac failure. Pronounced neck stiffness was present.

Results of investigations on admission were: haemoglobin concentration $11.3 \mathrm{~g} / \mathrm{dl}$; white cell count $7.5 \times 10^{9} / 1\left(7500 / \mathrm{mm}^{3}\right)$; platelet count $220 \times 10^{9} / 1\left(220000 / \mathrm{mm}^{3}\right)$; blood urea concentration $2 \cdot 2 \mathrm{mmol} / \mathrm{l}$ $(13.3 \mathrm{mg} / 100 \mathrm{ml})$; serum electrolyte values normal; total serum bilirubin concentration $49 \mu \mathrm{mol} / 1(2.9 \mathrm{mg} / 100 \mathrm{ml})$; and direct serum bilirubin concentration $46 \mu \mathrm{mol} / \mathrm{l}(2.7 \mathrm{mg} / 100 \mathrm{ml})$. Cerebrospinal fluid contained one polymorphonuclear leucocyte and 12 lymphocytes per high-power field and showed protein and glucose concentrations of $0.17 \mathrm{~g} / 1$ and $4.7 \mathrm{mmol} / 1(85 \mathrm{mg} / 100 \mathrm{ml})$, respectively; no organisms were seen or cultured. Apart from sinus tachycardia the electrocardiogram was normal. A chest radiograph showed extensive bilateral confluent opacification (figure). 